\title{
CONCEPTS OF COLLABORATION - SUPPLY CHAIN MANAGEMENT IN A GLOBAL FOOD INDUSTRY
}

\author{
Andrew Fearne, David Hughes \& Rachel Duffy \\ Imperial College at Wye \\ University of London
}

\section{INTRODUCTION}

Less than a decade ago, the days of the giant conglomerate seemed over; they were too big, too complacent and too inflexible. However, the US economy has grown fast since 1992 with many big organisations becoming flatter, less bureaucratic and hierarchical in structure. The big corporation of the 21 st Century looks like being a loose alliance, a confederation of small entities, held together by knowledge and competencies, shared values and integrated missions. The edges of these amorphous organisations will become more fuzzy, but, their control, through patents and contractual agreements seems likely to grow. The knowledge economy requires 'big science' and only big corporations with big R\&D budgets look likely to be able to afford it. Of course the human brain cannot continue to accommodate an exponential growth of knowledge and the 300 year old explosion of knowledge was flattening off by the 1960s. It is this diminishing returns to Research and Development that means the future belongs to the big corporation with deep pockets.

This chapter is concerned with the battle for supremacy in a food industry in which competition is played on a global field, with fewer, larger, global players battling for market share. The stalemate which results from global retailers confronting global manufacturers has been broken by the introduction of Efficient Consumer Response (ECR) and the realisation that co-operation between trading partners is more effective than confrontation. Traditional inter-firm competition is being superseded by competition between supply chains, as retailers and manufacturers alike seek competitive advantage through strategic supply chain partnerships.

The chapter is in three parts. We begin by looking at the retail sector, the process of globalisation and the emergence of food retailers as the dominant force in the food supply chain. The second part turns to the food manufacturing sector, in pursuit of a strategic response to retailer domination, with particular emphasis on the process of concentration and the changing competitive environment. Supply chain partnerships are explored in part three.

\section{THE GLOBALISATION OF GROCERY RETAILING}

The latter half of the $20^{\text {th }}$ Century, in both Europe and North America, has seen the emergence of the supermarket as the dominant grocery retail form. The reasons why supermarkets have come to dominate food retailing are not hard to find. The search for convenience in food shopping and consumption, coupled to car ownership, led to the birth of the supermarket. As incomes rose and shoppers sought both convenience and new tastes and stimulation, supermarkets were able to expand the products offered. The invention of the bar code allowed a store to manage thousands of items and their prices and led to 'just-in-time' store replenishment and the ability to carry tens of thousands of individual items. Computeroperated depots and logistical systems integrated store replenishment with consumer demand in a single electronic system. The superstore was born. 
The expansion of retailers across European borders has been one characteristic of structural change in industry in general and the food industry in particular (Table 1). Starting slowly in the 1970's, retail firms sought to extend their market territories within Europe. The pace of expansion accelerated in the 1980's and 1990's, with over half of post World War II retail firm moves within Europe being initiated during the 1990's:

Table 1 Retailers' Expansion Across European Borders, pre-1980s to 1997

\begin{tabular}{|l|c|c|c|}
\hline & Pre-1980s & 1980s & 1990s \\
\hline Percentage of Cross & 11 & 34 & 55 \\
Border Retail Moves & & & UK \\
\hline Top 5 Destinations & Belgium & Belgium & Spain \\
& France & Spain & Germany \\
& Austria & Germany & France \\
& Netherlands & UK & Czech Rep. \\
& Switzerland & Netherlands & UK \\
& UK & France & France \\
& Germany & UK & Germany \\
& France & Germany & Netherlands \\
\hline Top 5 Initiators & Netherlands & Outside Europe & Grocery \\
& Sweden & Italy & Fashion/Footwear \\
& Fashion/Footwear & Fashion/Footwear & Health/Beauty \\
& Grocery & Grocery & Household \\
\hline
\end{tabular}

Source: Oxford Institute of Retail Management and James Lang Wooton. 1997. Shopping for New Markets: Retailers Expansion Across Europe's Borders. Oxford Institute of Retail Management, Templeton College, University of Oxford. November, 1997.

The 1980's was a decade of "border hopping" where firms from many sectors expanded into adjacent markets - fashion retailers were most active in the first half; followed by the French grocery hypermarket companies (e.g. Carrefour) expanding into Spain, Italy and Greece, and German hard discount chains (e.g. Aldi) moving into adjacent countries in the second half. Cross-border alliances between non-competing national grocery retail firms were initiated with the intent of enhancing purchasing power and developing new product sourcing opportunities; for example, the European Retail Alliance/Associated Marketing Services. In North America, Wal-Mart experienced significant sales growth and expanded into Mexico. In South East Asia, Dairy Farm International started to build a strong regional presence;

In Europe, and led by grocery retailers, the "border hopping" accelerated during the 1990's, despite the economic recession early in the decade. With the end of the "Cold War", German and other Northern European retailers expanded into Eastern and Central European countries. Firms from Germany (e.g. Tengelmann), France (e.g. Carrefour), Belgium (e.g. Delhaize Le Lion) and the Netherlands (e.g. Royal Ahold) have taken a global perspective on trading. The major U.K. retailers have had less of an international presence - J Sainsbury in the USA; Tesco faltering in Northern France and, then, acquiring retail businesses in Eastern Europe and Thailand; although, Marks \& Spencer had established a network of franchises in selected major European centres in the previous decade;

The late-1990's has seen a flurry of merger and acquisition activity in the grocery retailing sector in North America as traditional supermarket companies restructure to counter the WalMart competitive threat - Wal-Mart, diversifying from its highly successful, but, non-food 
product dominated "big shed" (Sam's Club) format, started experimenting with smaller-scale retail formats and a comprehensive grocery product offer in 1998. In late-1997, Safeway took over Vons and, in 1998, Kroger's purchased Fred Meyer. In Canada, Loblaw's acquired Provigo and part of the Oshawa Group, while Sobey's (Empire) purchased the Eastern Canadian parts of Oshawa.

At the end of the Twentieth Century, there are three grocery retail firms - Wal-Mart, Carrefour, and Royal Ahold - who have strikingly similar global aspirations. For example, Royal Ahold's mission statement is "to grow quickly and profitably to become the world's leading supermarket company", a statement that is strikingly similar to that espoused by the other two major international players. However, the three firms have differing views on the preferred format for international expansion (viz. Ahold's supermarkets, Carrefour's hypermarkets, and Wal-Mart's "big shed" Sam's Club and smaller-scale super center formats).

Both "push" and "pull" factors (Table 2) explain the rationale for retail firms seeking to expand internationally. In northern Europe: push factors include the following: economic growth rates are, typically, modest and the population growth rate across the EU, for example, is barely at the replacement rate (average for the EU: $0.2 \%$ per annum); if not actually saturated, domestic markets are highly competitive, have a high cost structure, reflecting high labour, construction costs etc., and expansion is constrained by strict planning regulations that seek to control, even curtail, the expansion of out-of-town shopping centres (e.g. Germany, the Netherlands, France and, latterly, the U.K.), and/or competition policy legislation that is designed to protect the interests of consumers and suppliers.

\section{Table 2 Factors Explaining Global Expansion Initiatives by Major Grocery Retailers}

\begin{tabular}{|l|l|}
\hline Push & Pull \\
\hline - Market saturation at home & - Low retail concentration \\
- Slow growth at home & - Strong economic growth \\
- Adverse demography & - Pre-empt rivals \\
- Competitive market place & - Large population \\
- High cost structure at home & - High population growth \\
- Strict planning regulations & - Gain economies of scale \\
- Shareholder pressure to grow & - Relaxed regulatory environment \\
- Company ethos to go global & - Removal of entry barriers \\
- Me too or I'll get left behind" & - Suitable acquisition targets \\
- Financial markets encourage expansion & - Favourable cost structure \\
- Political instability & - Diversify to spread risk \\
- Leverage supplier relations & - Access to new capital \\
- Transfer know-how and extend core competencies & - Favourable exchange rates \\
& . Improved international communications \\
\hline
\end{tabular}

Source: Adapted from Oxford Institute of Retail Management and James Lang Wooton. 1997. Shopping for New Markets: Retailers Expansion Across Europe's Borders. Oxford Institute of Retail Management, Templeton College, University of Oxford. November, 1997.

Pull factors, in part, are the other side of the coin to the push factors identified above. Retailers seek countries that: have low retail concentration, albeit, with the prospects of high growth in supermarket sales; large populations and high population growth rate; incomes at or above the level that consumers start to discriminate between brands and have the income to exercise choice and in countries where income growth rate is high; and have favourable cost structures (e.g. low labour and construction costs), attractive exchange rates with the 
prospect of exchange rate gains over time, relaxed regulatory environments, and/or where entry barriers have been removed.

Other push and pull considerations underpinning an international expansion strategy include: gaining economies of scale in purchasing; a diversification mechanism for spreading commercial risk; gaining access to new ideas pertaining to supply chain management and retailing; transferring know-how and extending core competencies; and gaining leverage from the supply base established in countries that have become slow growth markets.

\subsection{Supermarketing Retail Strategy}

The genesis of the supermarket era - the emergence of the self-service grocery store - is attributed to retail developments in the USA. The first self-service food store was developed by Clarence Saunders in 1916 and sold mostly dry groceries. The first supermarket was opened in 1930 (King Kullen) by Michael Cullen, a New York merchant. Retail formats are very easy to copy (reducing the cost of entry for competitors) and self-service grocery stores emerged, at varying speed in the years immediately following the Second World War, as the major form of food retailing right across North America and Northern Europe. The principal merchandising model that emerged and was adopted by major supermarket chains can, for short hand, be labelled the "American model". The model can be characterised as having a wide range of branded goods, a narrower range of much cheaper own label/store brand products, with the promotional focus on price discounts, "specials" etc., and the stores leased, not owned, by the supermarket chain.

If the above form of retailing is the evolutionary "trunk", then, two significant branches emerged as alternates. First, German hard discount chains - small stores, very limited product offer (700 or so SKU's [stock-keeping units], rather than the 30,000+ that were more typical of USA supermarkets), with store/own label/secondary brands, and the focus almost exclusively on low price, with the very minimum of in-store service. Interestingly, this retailing form developed as a result of government regulation controlling the maximum size of retail stores within or proximate to population centres. The intent was, inter alia, to protect the small, independent retailer, but, the result was to encourage the expansion of chains of small format stores, such as Aldi and Lidl, who had difficulty in competing with the traditional trade on service and, therefore, elected to build a business on a low price offer. Hard discounters have a grocery market share in excess of 30 per cent in Germany and the competitive tone is unequivocally low price-low service.

The second major branch is the U.K. retailing model - out of town, company-owned super stores, 20-25,000 SKU's, of which as much as half may be own label/store brand items, positioned to compete with national brands on an equal quality and slight price discount basis. There is a strong emphasis on premium quality, chilled, almost exclusively own label value added food products. Company staff work closely with manufacturers of the own label products and new product development is prolific (e.g. J Sainsbury and Tesco, each launch around 1,500 new own label products per annum). The overall offer to the customer is value driven. Arguably, the U.K. model is, merely, a variant of the "American" model, with particular emphasis placed on premium own label and fresh foods. Certainly, it has delivered significantly enhanced margins to British grocery retailers (double or even triple the net profit margins of other countries). Its proponents argue that the U.K. shopper is well-satisfied. British shoppers do have the opportunity to patronise price-driven retail formats. For 
example, European hard discounters have a place, but, only a modest one in the U.K. grocery market (accounting for only a 6 per cent market share in 1999).

The focus on price competition and average quality - rather than service and/or high quality that is characteristic of most Northern European and North American food retailers is a selfreinforcing merchandising strategy that encourages periodic price wars. At relatively very low net profitability levels (i.e. 1-2\%), a small downturn in sales for the retailer is translated into a disproportionately high decline in net profitability (Table 3 ). In the example given, sales decline by a modest 2 per cent and, in the short term, the retailer has little flexibility in cutting costs. Some minor adjustments can be made, for example, reducing the usage of parttime staff to push variable costs down. The impact of this 2 per cent sales decline on net profit margin is an absolute decline of $\$ 300,000$, equating to a 29 per cent decline in percentage net margin. Once the retailer identifies that sales are down - and this, typically, means that less shoppers are coming into the store, rather than the regular shoppers buying less per visit - the reflex response is to reduce prices to attract shoppers back into the store.

Table 3 The Impact of a Sales Decline on Retail Net Margins: A Hypothetical Example

\begin{tabular}{|c|c|c|}
\hline & $\$$ & $\$>000$ \\
\hline Sales & 100 & 98 \\
\hline $\mathrm{COGS}^{1}$ & 80 & 78.4 \\
\hline Gross Margin & 20 & 19.6 \\
\hline Fixed Costs & 13.3 & 13.3 \\
\hline Variable Costs & 5.7 & 5.6 \\
\hline Net Profit $\left(\$^{\prime} 000\right)$ & 1.0 & 0.7 \\
\hline Net Margin $\frac{\text { (net profit) }}{\text { Sales }} \%$ & 1.0 & 0.71 \\
\hline
\end{tabular}

Source: Hughes, D. and D. Ray. 1999. The Global Food Industry in the $21^{\text {st }}$ Century, Food Industry Management, Wye College, University of London.

The relatively very high decline in net profitability occasioned by a modest downturn in sales is crucially important to the retailer operating on a low net margin because small decreases in net margin have a disproportional negative impact on return on equity (ROE) for the retailer. Of course, the reverse is, also, the case. A modest increase in sales boosts net margin sharply and, in turn, this has a very attractive impact on ROE. From the example (Table 4), a 0.1 per cent decline in net margin for the French or USA retailer translates into a tenfold decline in ROE, i.e. the ROE falls by a full percentage point. The U.K. retailer, operating at much more attractive levels of net profit margin, has substantially more latitude should there be a shortterm dip in sales. In the example given, a 0.1 per cent decline in net margin translates into a threefold decline, 0.3 per cent, in ROE - reason for considerable concern, but, not for mass panic and the slashing of product prices across the board. 
Table 4 The Impact of a Decline in Net Margins on ROE for Grocery Retailers

\begin{tabular}{|c|c|c|c|c|c|}
\hline ROE & $=$ & $\frac{\text { Net Profit }}{\text { Sales }}$ & $\mathrm{x}$ & $\frac{\text { Sales }}{\text { Assets }}$ & $\begin{array}{l}\mathrm{x} \quad \underline{\text { Assets }} \\
\end{array}$ \\
\hline $\begin{array}{l}\text { Return on } \\
\text { Equity }\end{array}$ & & $\begin{array}{l}\text { Net } \\
\text { Margin }\end{array}$ & & $\begin{array}{l}\text { Asset } \\
\text { Turnover }\end{array}$ & Leverage \\
\hline
\end{tabular}

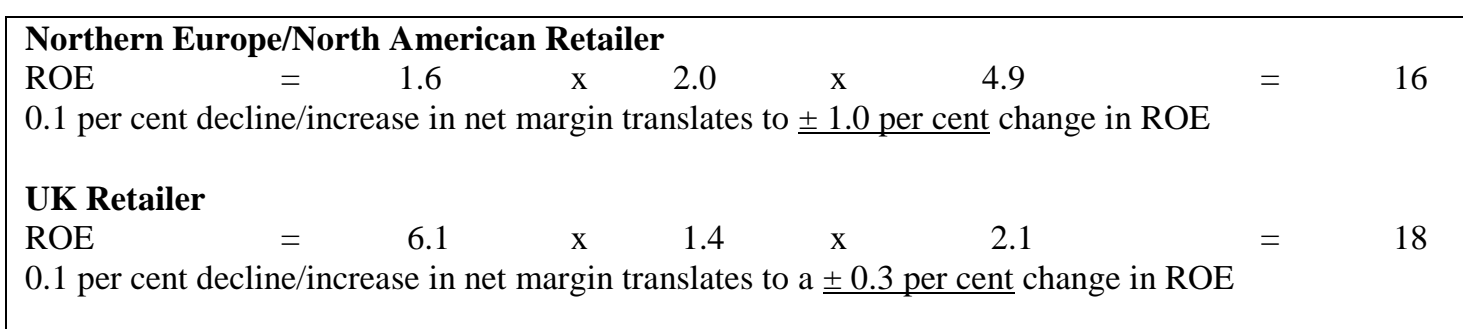

Source: Adapted from Wileman, A. and M. Jary. 1997. Retail Power Plays; From Trading to Brand Leadership. Macmillan Business Press, London, U.K.

Interestingly, the ROE of French/American grocery chains are not substantially different to those earned by the "high margin" U.K. retailers. Certainly, for shareholders, net profit margin is important, but, not as important as ROE. Table 4 illustrates that the financial structure of U.K. retailing differs fundamentally from the mainstream "American" retailing model. For the latter, it is the leverage, assets divided by shareholder equity, that is the driver of return on shareholder funds (ROE). As identified earlier, "American" model retailers are lean businesses with little investment in the physical stores, preferring to lease rather than purchase. The financial trump card in this form of retailing is to maximise the extent to which the business can be run on supplier credit (i.e. through gaining extended terms of payment) and, thereby, maximising leverage. In the U.K., the major retailers are "blue chip" quoted, public companies, with strong balance sheets reflecting, not least, their investment in, now, very scarce out of town sites for superstores, and the bricks and mortar of the stores themselves. This high level of capitalisation reduces leverage and identifies that U.K. retailers are in two businesses, viz. grocery retailing and property development and investment.

There are three principal implications of the "American" retail model focus on price, with service being an ancillary concern. First, there is consistent pressure within the supermarket business - from board level to store department manager - to reduce in-store labour, and to minimise head office staffing costs. This has the impact of reducing the quality of the shopping experience for the customer (e.g. few and low paid, untrained store-level staff to assist with in-store queries etc.), and reduces the time that head office staff have to develop effective commercial relationships with their suppliers and shoppers. This is despite research showing, year-in, year-out, that store cleanliness and staff helpfulness are key criteria in selecting which store to use for the major weekly shop. The 'American model' may suit the stores more than the customers.

Second, and linked to the most previous point, the totally price-driven model has the effect of fostering an ethos of constant confrontation between retailers and their suppliers manufacturers, distributors, growers etc. and for two reasons. Working with very slim net profit margins, retailers have come to rely on slotting fees and promotional allowances to bolster overall profitability. This is a pervasive retail practice on the continent of Europe and in North America, with Wal-Mart the outstanding exception insisting on a lowest price, net of any allowances (and passing the advantages of this on to its customers through its EDLP - 
Every Day Low Price - policy). Thus, the retail product offer has more to do with transfer payments from manufacturers to retailers than the presentation of a range of products that maximises shopper satisfaction. A slotting fee-led approach to determining product range at retail is sharply at odds with the ethos associated with the introduction of concepts such as Category Management (CM), and Efficient Consumer Response (ECR).

Third, the transfer of income from manufacturers to retailers - in the form of "street money" such as slotting fees - increases the comparative advantage of large versus small manufacturers through raising entry barriers to the food industry.

An almost exclusive focus on price, to the exclusion of other product attributes and supplier services, ensures that supplier-retailer relationships are, characteristically, confrontational and, in most cases, dominated by the retailer. Further, the merchandising tactic of using "specials" has convinced shoppers that they should only buy when many products are "on offer". This creates significant inefficiencies in the supply chain; for example, creating "spikes" in demand for products with the consequential requirement for suppliers and retailers to build up huge inventories in anticipation of abnormal demand. The combination of a frustrated shopper and a "bullied" supplier will serve to accelerate the demise of traditional supermarket retailing as it exists in the late-1990's. Clearly, there are supermarket firms to whom this does not apply (e.g. some American examples of best retailing practice would include Wegman's, H.E. Butt, Hannaford Bros.). However, for many, the final decade of the Twentieth Century may have been the supermarkets' halcyon period of domination in many markets in Northern Europe and North America.

The competitive threat for retailers is increasing as new routes to the shopper and consumer emerge. Traditional supermarkets have struggled to maintain market share in the face of increasing competition from growth sectors such as food service, warehouse clubs, gas station/forecourt "mini-supermarket" outlets, and the much-publicised, although still incipient, home delivery options using the internet, telephone etc. As shown in Tables 3 and 4 , a relatively small decline in sales for some supermarket companies which can result from this competitive pressure can have a draconian impact on net profit margin and ROE. The flurry of supermarket chain acquisition and merger activity in the latter part of the 1990's in Northern Europe and North America is testament to this as the more aggressive firms seek to consume their competitors and generate scale efficiencies in purchasing, logistics, and promotion etc.

\subsection{Changing Retailer Behaviour}

In the 1980's and early-1990's, retailers perceived that their stores were their greatest assets. Increasingly, successful retailers recognise that it is their customers who are their greatest assets. Thus, a race has been initiated to establish loyalty programs that will bind customers to specific stores through their lifetime - a cultural shift for retailers who, in history, were fixated on maximising transactions and traffic flow, irrespective of whether it was profitable traffic. Clearly, the current loyalty schemes represent the first tentative steps of retailers learning how to cope with the mountain of data that is generated through the bar codes on every product and every till. In many cases, the schemes are no more than discount programs that benefit shoppers who may or may not be profitable for the retailer in question. They have been beneficial in attracting trip loyalty rather than higher trip spend and spend is clearly the next target.The future emphasis will be a move from "one to many" mass marketing towards "one to one" mass customisation; 
The implementation of category management, as part of the global ECR initiatives, provides a scientific boost to the business of retailing as it relies on comprehensive analyses of storeand market-level data for making a wide range of strategic and tactical decisions. Further, it requires the retailer to appraise its relationships with key suppliers and to move away from confrontation and towards co-operation - this, in itself, is a cultural volte face that many will fail to attain. When retail buyers have been trained through the years to gain maximum leverage from their suppliers ("bullying" in many cases), and to consider all retail sales data as confidential, simply re-labelling the buyer as a category manager will not be sufficient to change the nature of the commercial relationship. Yet, category management is not "rocket science"! In the final analysis, it is simply getting the basics of retailing right, viz.: listing the consumer relevant SKU's; having them in-store at the right time; merchandising the display cabinet/shelfspace efficiently and effectively; providing effective promotional support; and ensuring price competitiveness on products that are price sensitive. In short, it is a matter of understanding the shopper and generating shopper and consumer enthusiasm for each product category and for the store overall.

Thus, to survive in the $21^{\text {st }}$ Century, traditional supermarkets must change radically. In essence, they must use IT and transformed staff to recreate the customer-retailer relationship that was characteristic of the very best specialist retailer businesses in the early $20^{\text {th }}$ Century. Radical changes will come quickly. AC Nielsen Europe surveyed 300 leading European Grocery retailer executives and asked them about the changes they expected to see in their sector in the first decade of the next Century. Responses to four of the key questions are instructive:

- What percentage of today's food retailers will be in existence in 2005? 63 per cent said less than 50 per cent.

- Who will own most of the stores in 2005? 65 per cent said large international/global retailers.

- If you were not in the food business, would you invest 50 per cent of your personal wealth in food retailing, today? 52 per cent said definitely not.

- By what date will consumer-direct sales represent 20 per cent or more of food "retail" volume? 20 per cent said by 2005 and 48 per cent said by 2010 .

If changes in the retail sector occur of the expected magnitude and at the expected pace, then, there will be substantial reverberation throughout the food industry. In the next section the consequences of such radical change for manufacturers are explored in more detail.

\section{FOOD MANUFACTURING - THE CLASH OF THE TITANS}

In this section, the focus is placed on the larger-scale manufacturing companies - fast moving consumer goods (FMCG) companies - such as Unilever, Kraft Jacob Suchard, Nestlé - and particular account is taken of their evolving relationships with major national and international retailers. First, structural changes in food and beverage manufacturing are addressed. Factors which stimulate international expansion of FMCG firms into global markets are reviewed. Briefly, the relative performance of food manufacturing firms is assessed, and initiatives that major FMCG firms can undertake to improve their commercial position vis-à-vis large-scale, often, global retailers are discussed. 


\subsection{Structural Changes in International Food and Beverage Manufacturing}

In the food and beverage industries of the developed world, the balance of power has shifted over the past 30 years or so to favour food retailers. This has been particularly marked in Northern Europe where national grocery markets are characterised by relatively high levels of retail concentration. This is in contrast to the USA, where retail concentration has been relatively low at the national market level, but, often high at the regional/state level.

In the early-1970s FMCG companies had field sales forces roaming the land and taking orders from individual shops. Promotions were local in orientation. In subsequent decades, the retail landscape became, increasingly, structured with supermarket chains consolidating, and the trade focus shifting to negotiations between retail head office and manufacturers. In the low growth 1990's, margins have been under pressure for most parties and the emphasis has shifted to capturing supply chain efficiencies to compensate for low growth. In the next decade, retailers will seek, as they are doing now, to reduce their supply bases and concentrate on building partnerships with preferred suppliers. Joint business planning will be initiated to build consumer demand, and to reduce logistics costs and improve supply chain management efficiencies.

While the globalisation of retailing is a relatively recent phenomenon, food manufacturing has been international in character for decades and, if not dominated, at least led by firms with their headquarters in the USA. The instigator of the convenience food revolution, the USA accounts for about one-fourth of the industrialised world's total processed food production. American firms comprise the majority of both the top ten and top thirty global food and beverage manufacturers. The UK is the next most frequently listed, followed by Japan and France (Table 5).

Since the 1970's, the nominal value of total world trade in processed food has increased at an average annual rate of about 10.5 per cent. This figure understates the importance of globalisation in the food industry, however, as it does not take into account the trans-national activities of food processing firms. For example: in 1994, sales from foreign affiliates of US processed food firms exceeded $\$ 100$ billion, more than four times the total value of US exports of processed foods. Most of these sales were in foreign markets; only about 2 per cent were shipped to the USA.

The EU food manufacturing sector is highly fragmented, although sales are dominated by companies with over 100 employees: in 1992, there were 256,000 food manufacturing firms each employing less than 20 people and accounting for 15 per cent of sector turnover; 4,500 firms with 100+ employees accounted for 70 per cent of sales turnover. Across-EU comparisons of changes in the size distribution of enterprises in the food and drink manufacturing sector from 1980 to 1992 is difficult, but, "the various pressures that we expected to promote concentration in the industry and lead to convergence of food industry structures across Europe appear to have had little impact during the 1980s". In the USA food manufacturing is much more concentrated: 16,000 registered food manufacturing firms in 1995, with the top 50 companies accounting for an estimated 50 per cent of total sector output. 
Table 5 The Top Thirty Food Manufacturing and Beverage Firms, Ranked by Food Sales, 1997.

\begin{tabular}{|c|c|c|c|c|}
\hline Rank & Company & HQ Base & $\begin{array}{r}\text { Food Sales } \\
\$ \text { billion }\end{array}$ & $\begin{array}{c}\text { Total Sales } \\
\$ \text { billion }\end{array}$ \\
\hline 1 & Nestlé & Switzerland & 45.4 & 47.6 \\
\hline 2 & Philip Morris & USA & 31.9 & 72.1 \\
\hline 3 & Unilever & UK/Holland & 24.2 & 48.5 \\
\hline 4 & Conagra & USA & 24.0 & 24.0 \\
\hline 5 & Cargill & USA & 21.0 & 56.0 \\
\hline 6 & PepsiCo & USA & 20.9 & 20.9 \\
\hline 7 & Coca-Cola & USA & 18.9 & 18.9 \\
\hline 8 & Diageo & UK & 18.8 & 20.2 \\
\hline 9 & Mars & USA & 14.0 & 14.0 \\
\hline 10 & Danone & France & 14.0 & 14.8 \\
\hline 11 & ADM & USA & 13.9 & 13.9 \\
\hline 12 & IBP & USA & 13.3 & 13.3 \\
\hline 13 & Anheuser-Busch & USA & 12.8 & 12.8 \\
\hline 14 & Kirin & Japan & 10.9 & 10.9 \\
\hline 15 & Sara Lee & USA & 10.4 & 17.9 \\
\hline 16 & Eridania Béghin-Say & France & 9.6 & 10.7 \\
\hline 17 & H.J.Heinz & USA & 9.4 & 9.4 \\
\hline 18 & Asahi Breweries & Japan & 9.1 & 9.5 \\
\hline 19 & RJR Nabisco & USA & 8.7 & 17.1 \\
\hline 20 & Best Foods & USA & 8.4 & 8.4 \\
\hline 21 & Suntory & Japan & 8.1 & 8.1 \\
\hline 22 & Campbell's Soup & USA & 8.0 & 8.0 \\
\hline 23 & Seagram & Canada & 7.0 & 12.6 \\
\hline 24 & Kellogg & USA & 6.8 & 6.8 \\
\hline 25 & $\mathrm{ABF}$ & UK & 6.8 & 8.5 \\
\hline 26 & Cadbury Schweppes & UK & 6.8 & 6.8 \\
\hline 27 & Heineken & Holland & 6.8 & 6.8 \\
\hline 28 & Tate \& Lyle & UK & 6.4 & 7.6 \\
\hline 29 & Tyson Foods & USA & 6.4 & 6.4 \\
\hline 30 & General Mills & USA & 6.3 & 6.3 \\
\hline
\end{tabular}

Source: Cooke, T. 1998. Leading Food and Drinks Groups. In: Trends in the Global Food Industry, 1998. Seymour-Cooke Food Research International, London, U.K.

Modest concentration although there may have been during the 1980s, the pace of structural change seemed to pick up during the 1990s. The early-1990's saw substantial polarisation taking place in the European food manufacturing sector. In 1991, the three largest companies - Philip Morris, Nestlé, and Unilever - posted European food sales of ECU 48.5 billion, out of a total European food sales of ECU 135 billion from the top 50 companies, i.e. 36 per cent of total. The corresponding figure in 1988 was 23 per cent and, by 1994, it had increased to close to 50 per cent. By the early part of the 1990's, the major sub-sectors of the European food-manufacturing sector showed a relatively high degree of three firm concentrations in most EU countries (Table 6). With the exception of pasta in the U.K. (a relatively underdeveloped market in European terms), the top three manufacturers accounted for more than 50 per cent of output in the pasta, coffee, biscuit, chocolate confectionery, ice cream, and mineral water product areas. Within the selected NACE codes, the leading manufacturers are, typically, multinational firms with a strong European presence at the least and, generally, a global presence (Table 7).

Table 6 Three Firm Concentration Ratios for Selected Food Product Categories, 1991

\begin{tabular}{|l|c|c|c|c|c|c|}
\hline & Pasta & Coffee & Biscuits & $\begin{array}{c}\text { Choc. } \\
\text { Confect. }\end{array}$ & Ice Cream & $\begin{array}{c}\text { Mineral } \\
\text { Water }\end{array}$ \\
\hline UK & 27 & 78 & 70 & 79 & 58 & 50 \\
France & 58 & 64 & 50 & 51 & 56 & 76 \\
Germany & 57 & 63 & 50 & 51 & 88 & 24 \\
Italy & 52 & 67 & 67 & 50 & 80 & 34 \\
\hline
\end{tabular}

Source: Fearne, A. 1996a. The Impact and Effectiveness of the Internal Market Programme on the Processed Foods Sector. Food Industry Management Group, Wye College, University of London, January, 1996. 
Table 7 Major Manufacturers of Selected Food Product Categories (by NACE code) in the Early 1990s

\begin{tabular}{|l|l|l|l|l|}
\hline $\begin{array}{l}417 \\
\text { Pasta }\end{array}$ & $\begin{array}{l}423 \\
\text { Tea/Coffee }\end{array}$ & $\begin{array}{l}419 \\
\text { Biscuits }\end{array}$ & $\begin{array}{l}421 \\
\text { Confectionery }\end{array}$ & $\begin{array}{l}421 \\
\text { Ice Cream }\end{array}$ \\
\hline Barilla & Douwe Egberts ${ }^{1}$ & Bahlsens Keksfabrik & Cadbury & Unilever \\
Danone & Jacobs Suchard $^{2}$ & Campbell & Ferrero & Scholler \\
RHM & Nestlé & Danone & Suchard & Nestlé \\
Nestlé & Unilever & United Biscuits & Mars & Mars \\
Heinz & & RJR Nabisco & Nestlé & Grand Met. \\
\hline
\end{tabular}

\begin{tabular}{|l|l|l|l|}
\hline 424 & 427 & 428 & 428 \\
Spirits & Beer & Soft Drinks & Mineral Water \\
\hline Allied Domecq & Anheuser Busch & Coca-Cola & Nestlé \\
Grand Met. & Bass & Pepsi-Cola & Danone \\
Seagram & Danone & CCSB & San Benedetto \\
Guinness & Fosters & Bass & San Pellegrino \\
& Heineken & & \\
\hline
\end{tabular}

\footnotetext{
Sara Lee

2 Phillip Morris

3 Coca Cola Schweppes (Cadbury) Beverages

Source: As per Table 6
}

Concentration levels in the branded food product business, however, are modest relative to other FMCG product categories such as detergents, and household paper products (e.g. toilet paper, nappies/diapers, kitchen towels). In 1998, seventeen of the top twenty branded products in those categories (measured by sales value) in the U.K. were manufactured by three firms alone - Unilever, Procter and Gamble, and Kimberley Clark - who have a similarly strong market position right across the other fourteen EU countries. This serves to emphasise the point that there is intrinsically greater difficulty in establishing pan-European, or global, brand names for food products than for household non-food items and health and beauty care products.

In the early 1990s, merger and acquisition (M\&A) activities of major food manufacturing and beverage companies in Europe was intense - accounting for close to two-thirds of all M\&A activity in the global food industry - and, largely, cross-border as companies within the EU "jockeyed" for commercial position. By mid-decade, the global M\&A activity remained at historically high levels, but, the proportion accounted for by EU firms had declined (38 per cent of total), and the logical M\&A "targets" within Europe had been addressed - or, at least, addressed by the major FMCG firms. Around half of all EU firm M\&A's were focused at other firms outside Europe in 1996 (Table 8).

Western European and U.S. firms have dominated M\&A activity during the 1990s accounting for 70 per cent of total M\&A's in 1996. Globally, most M\&As are cross-border and, often, for non-EU and non-US firms, involve purchases of/mergers with firms in adjacent countries. American firms accounted for around one-third of all M\&As in the mid1990s, followed by firms from the U.K., France, Canada and Germany (Table 9). M\&As are spread out over the food and beverage industry by product category (Table 10), although are particularly noticeable in the alcoholic and soft drink sectors (20 per cent of global total), and the dairy sector. 
Table 8 Food and Beverage Industry Mergers and Acquisitions, by Major Regions, 1994-96

\begin{tabular}{|l|r|r|r|l|c|}
\hline Region & $\mathbf{1 9 9 4}$ & $\mathbf{1 9 9 5}$ & $\mathbf{1 9 9 6}$ & $\begin{array}{l}\text { Percentage } \\
\text { Cross-Border in } \\
\mathbf{1 9 9 6}\end{array}$ & $\begin{array}{l}\text { Percentage of total } \\
\text { M\&A in 1996 }\end{array}$ \\
\hline Western Europe & 214 & 262 & 202 & 49 & 38 \\
Central/Eastern Europe & 29 & 38 & 35 & 86 & 7 \\
North America & 143 & 158 & 168 & 22 & 32 \\
Latin America/ & 33 & 42 & 52 & 92 & 10 \\
Caribbean & & & & & 9 \\
Asia/Pacific & 47 & 44 & 48 & 85 & 4 \\
Africa/Middle East & 17 & 15 & 23 & 74 & $\mathbf{1 0 0}$ \\
Total & $\mathbf{4 8 3}$ & $\mathbf{5 5 9}$ & $\mathbf{5 2 8}$ & $\mathbf{5 1}$ & \\
\hline
\end{tabular}

Source: Cooke, T. 1994 and 1998. Mergers \& Acquisitions World-Wide. Seymour-Cooke Food Research International, London, U.K. 1994 and 1998.

Just as retailers have established horizontal, cross-border alliances with each other in Europe, Northern Hemisphere-based food manufacturers have undertaken similar initiatives. In the early 1990s, Nestlé and Coca-Cola formed the Coca-Cola-Nestlé Refreshment Co. to develop ready-to-drink tea and coffee markets outside Japan. Unilever linked up with Pepsi-Cola to develop tea-based drinks and Danone to market frozen yoghurt products. Most active has been General Mills, from the USA, linking with Nestlé to form Cereal Partners Worldwide, Pepsico, to focus on the European snack market, and Best Foods to launch desserts and baking mixes in eight Latin American countries.

Table 9 Merger and Acquisitions (M\&A) by Headquarters Location of Lead Firm 1994 and 1996

\begin{tabular}{|l|r|r|}
\hline \multirow{2}{*}{ HQ Location of Lead Firm } & \multicolumn{2}{|c|}{ Percentage of Total M\&As } \\
\cline { 2 - 3 } & $\mathbf{1 9 9 4}$ & $\mathbf{1 9 9 6}$ \\
\hline USA & 32 & 35 \\
UK & 20 & 14 \\
France & 6 & 10 \\
Canada & 7 & 6 \\
Germany & 7 & 5 \\
Italy & 4 & 4 \\
Spain & 5 & 4 \\
Netherlands & 4 & 4 \\
Poland & 2 & 3 \\
Australia & 3 & 3 \\
& & \\
Others & 10 & 12 \\
\hline Total & $\mathbf{1 0 0}$ & $\mathbf{1 0 0}$ \\
\hline
\end{tabular}

Source: as per Table 8. 
Table 10 Global Merger and Acquisitions Activity by Major Product Category 1994 and 1996

\begin{tabular}{|l|c|c|}
\hline \multirow{2}{*}{ Product Category } & \multicolumn{2}{|c|}{ Percentage of Total M\&As } \\
\cline { 2 - 3 } & $\mathbf{1 9 9 4}$ & $\mathbf{1 9 9 6}$ \\
\hline Dairy & 10 & 9 \\
Baking \& Milling & 9 & 8 \\
Beer & 8 & 7 \\
Fruit \& Vegetables & 8 & 8 \\
Soft Drinks & 8 & 9 \\
Meat & 8 & 7 \\
Ingredients & 7 & 8 \\
Miscellaneous & 7 & 7 \\
Frozen \& Ice Cream & 5 & 8 \\
Wine \& Spirits & 4 & 3 \\
Biscuits & 4 & 2 \\
Confectionery & 4 & 4 \\
Fish & 3 & 5 \\
Oils \& Fats & 3 & 3 \\
Savoury Snacks & 3 & 3 \\
Herbs, Spices, Sauces & 3 & 2 \\
Pet/Animal Feeds & 2 & 2 \\
Baby Food & 2 & 1 \\
Sugar & 1 & 2 \\
Tea/Coffee & 1 & 2 \\
& & $\mathbf{1 0 0}$ \\
Total & $\mathbf{1 0 0}$ & \\
\hline Source: As per Table 8 & \\
\hline
\end{tabular}

Source: As per Table 8

The three most commonly cited reasons for forming alliances are: to gain access to a market, and/or a distribution system; to exploit complementary technology; and to reduce time taken for innovation. Alliances are, likely, to be a sustaining feature of the food manufacturing scene.

\subsection{Increasing Competitive Environment in Food Manufacturing}

Food manufacturers view the emergence of a relatively few, very large global retailers with some trepidation. The major FMCG food manufacturers have first hand experience in dealing with major national retailers in the mature market regions of Northern Europe and North America and, more recently, it has been a struggle.

From a period of market dominance in the 1950's and early-1960's, manufacturers have come under increasing commercial pressure from major retail chains who, now, are expanding aggressively on a global basis. In their home markets, food companies have learnt that strong brands and market leadership is critical to fending off the challenge of retailer own label products. This is particularly the case for premium own label products such as those offered by J Sainsbury in the U.K., Safeway Select in the USA, and President's Choice of Loblaw's in Canada; although, even in the USA - where own label sales were slow to become established, now, they are forecasted to increase at three times the rate of nationally branded grocery products.

The launch of the Europe currency program at the beginning of 1999 has served to compound the challenges for the multinational FMCG companies and is a harbinger of what is to come when the global retailers elect to source globally and seek a single net price from their major 
suppliers. Manufacturer selling prices for FMCG products have varied significantly across the European Union as manufacturers have sought to exploit their bargaining position by country reflecting, in the past, that retailing was on a national basis. Cross-border mergers have "Europeanised" the market. With the introduction of the Euro, and removal of exchange rate risk price differentials between markets will become more transparent. For example, German retailers may wish to quiz Coca-Cola on the rationale for the 100 per cent price differential between Germany and Spain for a 1.5 litre bottle of Coke! The French food retailer, Promodès, operates in France, Belgium, Italy, Spain and Portugal and, indubitably, will be demanding one price and the very lowest price from Coca-Cola for all its companies in Europe.

\subsection{Combating the Competitive Threat from Global Retailers: FMCG Initiatives}

There are a range of responses that FMCG companies can consider as mechanisms to combat the growing competitive threat from increasingly powerful global retailers:

- Innovate - in general, retailers' own label products are copies of manufacturer brands and retailers have no history of significant investment in NPD directly and/or via their own label suppliers. FMCG firms have the resources to invest in a high level of R\&D expenditure to develop products which have proprietary technology. At 1.2 per cent of sales, $R \& D$ expenditure in the international food industry is at very modest levels relative to the 10-12 per cent levels of the pharmaceutical and health care industries. Clearly, FMCG firms must continue to innovate, if they are to provide a food product range that is identifiably different and more desirable than the retailers' own label offer. However, innovation should not be simply product related. Firms should seek to innovate in everything that they do - supply chain management, IT, customer management, demand management and, even in entrepreneurship, to convince employees that innovations that fail are a fact of life, but, failure to innovate is inexcusable and tantamount to a death wish!

- Cost Leadership - through the 1990's, firms world-wide have sought to "downsize" or "re-engineer" to cut costs and remain competitive. Notwithstanding the plausibility of Michael Porter's generic business strategies, cost consciousness and leadership is a necessary condition for market leadership. However, another Porter concept - value chain analysis - is apposite. It is counter-productive to cut costs and, through doing so, reduce customer value by an even greater amount. The challenge is to identify what customers value and are willing to pay for. Then, to focus on the key drivers of cost advantage viz. economies of scale, and of learning, production techniques, product design, input costs, capacity utilisation, and managerial/organisational efficiency - and their minimisation, keeping customer requirements firmly in sight.

- Diversify Sectors within Existing Geographical Markets - to-date, the supermarket sector has attracted the lion's share of attention for FMCG companies, as this has been the sector with the greatest volume and value. However, its relative importance is declining and there are other routes to the consumer; for example, there is continued growth in the food service sector. In history, food service has not been well-serviced itself. Products focused at this sector have tended to be the wholesale box and/or larger size versions of products that are merchandised at grocery retail. Further, what was once a fragmented sector, difficult to service, is becoming increasingly concentrated and merits the attention to customer requirements that has been characteristic of the grocery retail sector. 
- Explore New Distribution Channels - new routes to the consumer are emerging which bypass the main line grocery sector. The much-discussed internet shopping, and/or the more generic home delivery sector, offers substantial potential for the future. Even if these routes capture a small share of the overall grocery market, in absolute dollar terms, they are not niche markets and can generate both significant value and volume.

- Seek to develop long-term partnerships with those retailers who will lead the industry in the future. Partnership development, like any investment, often is both human and capital resource intensive. The current industry interest in category management and ECR - both resource-intensive concepts to implement in practice - provides major companies, in particular, with substantial opportunities to gain "category captain" status, and garner the competitive advantage that such a position can bring.

The emergence of supply chain management as a source of competitive advantage and the growing emphasis on the development of strategic supply chain partnerships within the global food industry is a relatively recent phenomenon. It is also one of the challenges which retailers, food manufacturers, farmers and all the other intermediaries in the food supply chain find particularly difficult to tackle. This chapter concludes with a discussion of the principles of supply chain management and the key requirements for the development of strategic supply chain partnerships in the global food industry.

\section{SUPPLY CHAIN PARTNERSHIPS FOR A GLOBAL FOOD INDUSTRY}

It is commonplace today for strategic writers to argue that competition is dead (Moore, 1996), or that co-opetition rather than competition is the way forward (Brandenburger \& Nalebuff, 1996). At the operational level there has also been a plethora of writing about more collaborative relationship management, and procurement and logistical effectiveness and efficiency that draws on this experience. The work by Bhote (1989), Carlisle and Parker (1989), Christopher (1992 \& 1997), Gattorna and Walters (1996), Harrison (1993), Hines (1993), Houlihan (1988), Kay (1993), Lamming (1993), Lewis, (1990), Sako(1992) and Saunders (1994) all falls into this category.

The basic argument of this writing is that business success will be derived from companies managing enhancing the total performance of the supply chain, so that it can deliver improved value to customers. Thus waste is normally seen as the major enemy, and closer and long-term working relationships--even partnerships--with suppliers at all levels in the chain are recommended in order to deliver exceptional value to customers. Companies are, therefore, instructed to construct ever more efficient and responsive supply chains because it will no longer be company competing with company, but supply chain competing against supply chain.

The development of collaborative marketing ventures in the global agri-food chain is a response to the economic pressures that are driving the evolution of the chain and encouraging greater vertical and horizontal co-ordination. To some, such vertical and horizontal collaborative ventures ('linkages', 'alliances', 'value-added chains' or 'partnerships) are seen as a compromise in market organisation between the extremes of open market trading and complete vertical integration. To others, they offer an alternative less rigid way of co-ordinating the market. 
The supply chain has been defined by Christopher (1992) as a network of organisations that are involved through upstream and downstream linkages in the different processes and activities that produce value in the form of products and services in the hands of the ultimate consumer. Thus, a supply chain consists of a number of businesses through which information concerning demand flows upstream from the marketplace and ultimately to the raw material supplier. Material flows downstream, ending up as the particular physical product satisfying end-customer needs.

Cox (1999) argues strongly that the supply chain concept has both a strategic as well as an operational importance. Thus, he regards the supply chain as having two dimensions. The first can be referred to as the operational supply chain; the second can be referred to as the entrepreneurial supply chain.

The operational supply chain refers to the series of primary and support supply chains that have to be constructed to provide the inputs and outputs that deliver products and services to the customers of any company. All companies have operational supply chains, and these supply chains are normally unique to the company creating them, because they have choices about the input and output supply chains that they create operationally, when they position strategically to provide a particular product and service within a specific primary supply chain.

This notion of companies positioning strategically within a primary supply chain is an underdeveloped aspect of thinking in business strategy. It is true that Porter (1980) was well aware of the importance of buyer-seller relationships in the development of his famous Five Forces Model. However, Cox argues, that strategic management thinking has systematically underestimated the importance of these types of vertical business-to-business relationships as the basis for a proper understanding of entrepreneurial action and sustainable business success. Furthermore, it is clear that supply chain thinking can provide a significant insight into the conduct of business strategy, and that it is not merely an operational tool or technique.

In recent years the idea of companies focusing on their core competencies has been muchpromulgated (Hamel and Prahalad, 1990). Indeed, one could say that it has been the dominant thinking in strategic management in the 1990s. The core competence paradigm is based on companies understanding what internal skills and resources they should own and control through internal contracts in order to sustain their business success. It is also based on the understanding that the key strategic decision within the company--the entrepreneurial makebuy decision--is always a supply chain management one.

When companies decide to become involved in any supply chain they have to make decisions about how they will control and manage the primary supply chain itself. They face decisions about where they should position in the chain. At one extreme they can decide to vertically integrate the whole chain from raw materials to end customer, or they can decide to own only one or two of the resources that exist in the chain.

It is clear that in an ideal world companies ought to position strategically to own those supply chain resources that are difficult to imitate, and around which they can build defensible barriers to market entry. Only by possessing supply chain resources that have a low propensity for contestation is it possible for superior performance to be achieved by companies over the long-term. It follows, therefore, that ideally companies must only 
outsource those supply chain resources that are highly contested and which have low barriers to market entry. In this way it is likely--if the company also understands how to limit its dependency on suppliers and how to continuously monitor any threats to its own supply chain position from suppliers--the company will be able to maximise its ability to appropriate value for itself.

This is what is meant by strategic, or entrepreneurial, supply chain thinking. It is a way of thinking that recognises that, for whatever is produced for customers, it will always require the construction of an entrepreneurially defined, generic supply chain. Within this chain there will be resources around which there is a variable scope for contestation and market closure. Historically strategy has tended to concentrate on horizontal competitive rivalries around particular supply chain resources, rather than on knowing entrepreneurially where to position to own and control particular resources within a specific supply chain in order to appropriate the maximum share of value for oneself.

In practice, the concept of supply chain management is relatively new, first appearing in the 1980s and emanating from the Japanese motor industry (Womack, Jones and Roos, 1990).. The Japanese management philosophy, 'Kaizen', which means continual improvement, is at the core of supply chain management. The Japanese were the first to recognise that in increasingly competitive markets, continual improvement, however it is measured in a business context, is increasingly difficult to achieve when business organisation work in a vacuum. The paramount importance of meeting consumer needs more quickly, more effectively and more efficiently led them to share their strategic vision with their suppliers and their distributors and invite members of their respective supply chains to contribute to the process of making the Japanese motor industry the 'best in class'.

Following the success enjoyed by the Japanese motor industry during the late 1980s and early 1990s, manufacturers worldwide began to view their supply chains as an important source of competitive advantage. Initially, the emphasis was on logistics and the reduction of leadtimes and inventory levels, reducing uncertainty and making better use of production capacity and hitherto under-utilised resources. Thus, efficiency was the key driver at the outset. More recently, the emphasis has moved towards innovation and the creation of value-added in the supply chain, with new product development and improved customer service a key motive for supply chain management in the new millennium, embracing new technology and capitalising on the information revolution which have been created by the Internet.

The food industry has been slow to emulate the success of the motor industry and it is only in recent years that supply chain management has made its way onto the boardroom agendas of the world's leading food manufacturers. Progress has been particularly slow upstream, where a distinct lack of trust between trading partners has made the task more difficult and the process longer. O'Keeffe (1998) identifies four key characteristics in the agri-food sector that have historically impeded the process of trust-building at the grow-processor interface:

- In commodity markets the sum of value created is fixed and the major issue is how it is divided among channel participants. This is a win-lose game and leads to adversarial relationships;

- Auction systems and regulated markets isolate farmers from the rest of the food system and farmers do not gain any insight into their customers, and why they act the way they do. Likewise processors have not needed to, or had the opportunity to, develop 
relationships with growers;

- Supply Chain Management does not remove the volatile nature of prices and supply - both quantity and quality - characteristic of agriculture. Price volatility puts pressure on the relationship;

- Interdependence is difficult to achieve owing to size imbalance between processors and farmers.

However, the launch of the Efficient Consumer Response (ECR) initiative, initially in the US grocery industry and later throughout Europe, represented a paradigm shift in the operation of the food supply chain, with adversarial trading relationships being replaced by co-operation and co-ordination, facilitated by a willingness to exchange information of both strategic and operational importance. As a result, the world's leading food manufacturers are shaving days off of production lead times, weeks off of inventory levels and months off of New Product Development (NPD) cycles, delivering a more effectively managed range of carefully targeted products and services to increasingly diverse groups of consumers, at substantially lower costs. The commodity sectors have still a long way to catch up, but it is evident that throughout the global food industry supply chain management is here to stay and likely to remain a key point of focus for the leading players in the future.

\subsection{The principles of supply chain management}

What is most striking about the principles of supply chain management is that they are extremely simple, yet implementation invariably proves problematic. The following definitions demonstrate the scale and scope of supply chain management from a functional, process, and business philosophy perspective.

Supply chain management is...

"... the process of planning, implementing and controlling the efficient, cost-effective flow and storage of raw materials, in-process inventory, finished goods and related information from point-of-origin to point of final consumption for the purpose of conforming to customer requirements" (Council of Logistics Management, What is it all about?., Oak Brook, IL, 1986)

"... the integration of business processes from end user through original suppliers that provides products, services and information that add value for customers" (The International Centre for Competitive Excellence, 1994)

"... working together in all activities of the firm: Planning (strategic and tactical), Operations (purchasing, manufacturing, sales, marketing, distribution, NPD), Human Resource Management, Monitoring \& Control (feedback)" (Fearne, A. 1996. Editorial, International Journal of Supply Chain Management, Vol.1, No.2)

In simple terms, supply chain management is concerned with the sharing of information, in order to:

- Save time (markets across the world are becoming increasingly dynamic and Product Life Cycles are getting shorter) 
- Reduce costs (manufacturing, inventory, distribution and waste)

- Increase effectiveness (accurate targeting of consumer needs and wants)

- Add value (innovation in new product development and customer service remains the only sustainable source of competitive advantage, difficult to achieve and most difficult to emulate)

In practice, implementing supply chain management is complicated by the fact that it requires a fundamental change in the way firms operate. It is not merely a case of doing something better, it requires strategic managers to have an open mind towards the alternative ways of getting things done (e.g. the 'make or buy' decision) and effective mechanisms for communicating strategic objectives to operational staff, who live in fear of rationalisation and outsourcing. It also requires strategic managers to re-visit the question of core competence and competitive advantage from the perspective of the entire supply chain not merely from where they are positioned. The problem here is that this represents a major threat to the status quo - existing authority relationships, responsibilities and the balance of power, within and between firms operating in the supply chain.

Figure 1 illustrates the basic structure of the food supply chain, which combines the 'push' of value-added material flow, from the breeding of genetic stock downstream right through to retail, with the 'pull' of information from the final consumer upstream right through to the production of raw materials.

The supply chain comprises functions (what people and organisations do), such as those depicted in Figure 1, and processes (the way in which things get done), which link the functions and translate the information flow into value added activity, throughout the supply chain.

Figure 1 Basic structure of the food supply chain

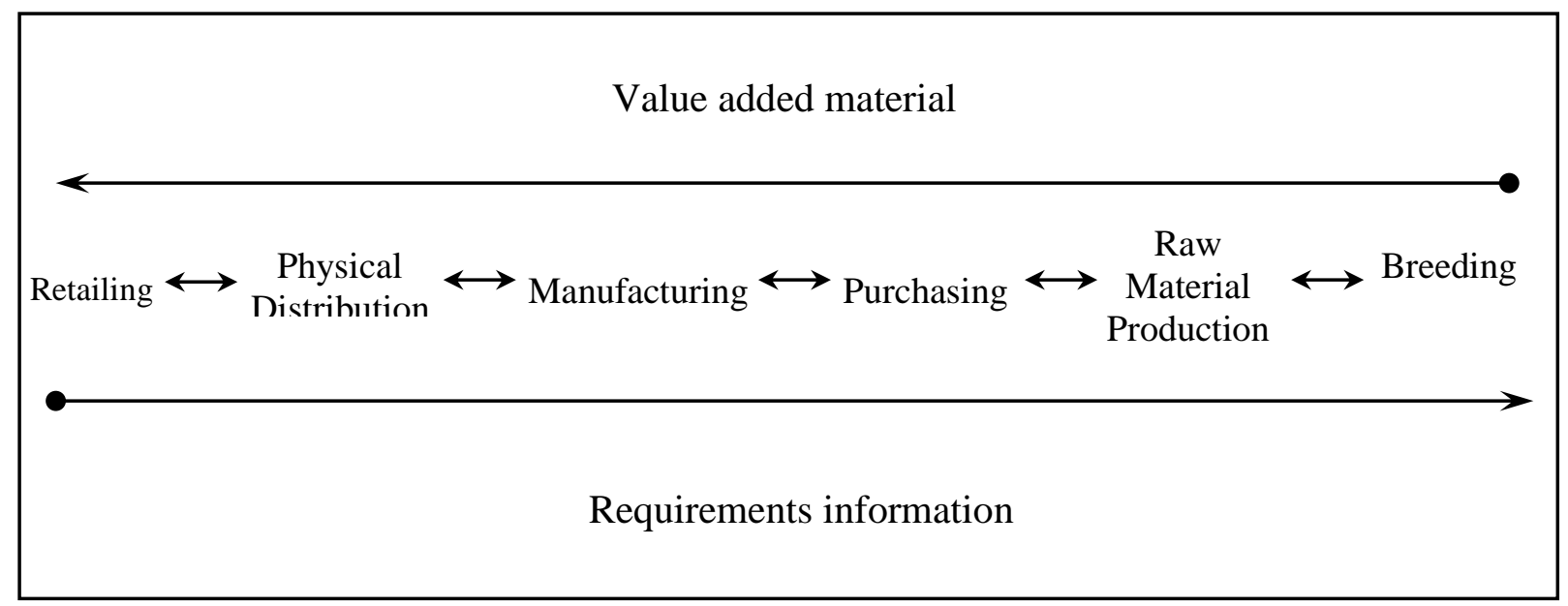

The focus of supply chain management is explicitly on processes - finding the most effective and efficient way of adding value - with the aim of generating cross-functional solutions to the many complex problems associated with meeting consumer requirements effectively and at minimal cost. Cross-functionality may occur within an organisation (e.g. sales, marketing, logistics, and production combining to reduce inventory levels whilst maintaining customer service levels) or between organisations (e.g. third party logistics, production planning and growers combining to manage raw material supplies in a way that optimises short term 
storage and the utilisation of vehicle and processing capacity), depending on who does what and how - the fundamental questions which supply chain management aim to address.

As far as the food processing supply chain is concerned, the functions are known to all and not open to question: The production of raw materials for processing requires breeding, production, storage and distribution, the procurement of other inputs and the management of a number of discrete 'production functions'; agricultural commodities are subject to grading and storage will be necessary for some, as will further preparation for certain markets; procurement of raw materials is undertaken in tandem with the scheduling of various production processes (continuous rather than discrete) within the processing plant; finished products are then stored and distributed to retail distribution centres, where consolidation takes place prior to distribution to retail stores, where merchandising and marketing activities complete the process from the selection of genetic stock to the purchase of the finished product.

However, whilst most, if not all of the functions necessary for the transformation of raw materials into finished food products are universally accepted, the way in which they are undertaken, individually and in combination are not - there is no consensus regarding the most effective and efficient way of combining these functions to secure competitive advantage.

What is quite clear is that in order for any process to be completed efficiently there needs to be effective communication between and within all organisations involved. In theory, market forces and the dynamics of competition will force the discovery or adoption of 'the one best way', as failure to do so will, other things being equal, result in loss of market share. However, sharing information poses a real threat to independence, particularly when those involved lack mutual trust and have a tendency to behave opportunistically, with a short term planning horizon - a real challenge for supply chain management.

\subsection{Theoretical perspectives on supply chain partnerships}

Hobbs (1996) suggests that Supply chain management can be viewed as a continuum of vertical integration. At one extreme lie spot markets where goods are exchanged between multiple buyers and sellers in the current time period, with price as the sole determinant of the final transaction. In other words, other aspects of the transaction are non-negotiable - the buyer either accepts the product in its current form, or does not purchase it. Examples of spot markets are auction markets, stock markets and most consumer good purchases (e.g. purchases of food in a supermarket). In a spot market transaction, management of the supply chain, in any formal sense, is entirely absent. At the other end of the vertical co-ordination spectrum lies full vertical integration, where products move between various stages of the production-processing-distribution chain as a result of within-firm managerial orders rather than at the direction of prices.

In between the two extremes of spot market transactions and vertically integrated firms lie a myriad of alternative ways of co-ordinating economic activity, from strategic alliances and formal written contracts, to vertical integration. These represent different degrees of supply chain management - some more formal than others. A strategic alliance is an agreement mutually entered into by two independent firms to serve a common strategic objective. It is often more flexible than a contract or full vertical integration. Central to the success of a strategic alliance are trust between firms and a strategy which is to the mutual benefit of all 
the participants; sometimes the alliance may also place legal obligations on the parties. For example, a meat processor might reach an agreement with a group of pig producers to obtain finished pigs of a certain quality, providing producers with a list of acceptable breeders. A meat processor might also introduce a high quality packaged pork product jointly developed with a major retailer under a strategic alliance (Sporleder, 1992).

Under a contract, a firm usually devolves control over various aspects of the supply chain i.e. marketing and/or production of its product - to a buyer. Contracts can be classified into three broad groups (Mighell and Jones, 1963): (1) Market specification contracts represent an agreement by a buyer to provide a market for a seller's output. The seller transfers some risk and the decisions over when the product is sold and how it is marketed to the buyer. Control over the production process, however, remains with the seller. (2) A productionmanagement contract gives more control to the buyer than a market-specification contract. The buyer participates in production management through inspecting production processes and specifying input usage. (3) Even more control rests with the buyer in the case of resource-providing contracts in which the buyer provides a market outlet for the product, supervises its production and supplies key inputs. Often, the buyer may own the product, with the seller paid according to the volume of output. This is the closest contractual arrangement to full vertical integration. For example, a feedstuffs manufacturer might contract with pig producers, supplying feedstuffs, overseeing production methods and marketing the finished pigs.

Quasi vertical integration refers to a relationship between buyers and sellers that involves a long-term contractual obligation where both parties invest resources in the relationship. It differs from full vertical integration because the arrangement ceases at the end of an agreed period of time and the firms remain independent of one another. A joint venture is one example of quasi-integration. Participants share the costs, risks, profits and losses of the venture. Franchises and licences are other examples of quasi vertical integration.

Tapered vertical integration occurs when a firm obtains a proportion of its inputs through backward integration with a supplier. For example, a beef processing firm integrated backwards into beef production could obtain a proportion of its beef supplies from its own farms with the remainder procured from auction markets or direct from beef producers. Alternatively, a firm could transfer a proportion of output forward through its own distribution network with the remainder sold on the open market.

Full vertical integration occurs when one firm carries out two or more consecutive stages of the production-distribution chain. A firm can be integrated forwards (downstream) into distribution or retail functions or backwards (upstream) into supply functions.

An alternative way of viewing supply chain partnerships is proposed by Lorange and Roos (1993), who choose to focus on the degree of interdependency between trading partners. At one extreme lie informal co-operative ventures, low on inter-dependency and easy to get out of, while at the other extreme we find mergers and acquisitions, where the parties are highly inter-dependent and the relationship is very difficult to reverse. In between we find formal co-operative ventures, strategic alliances, joint ventures and joint ownership, representing alternative forms of partnership arrangement with increasing levels of inter-dependence.

Traditionally the marketing literature has viewed exchange between buyers and sellers as taking place on an ad hoc basis in the competitive marketplace. Firms who wished to avoid 
the market could do so by backwards or forwards integration. Based on these traditional views of exchange, exchange is conceptualised as existing on a continuum with pure market transactions at one end and hierarchical within firm transactions at the other. In-between these two extremes Williamson (1975) suggested that the market mechanism could be modified through some kind of formal or informal contractual arrangement between the parties involved.

Traditionally, channel relationships have tended to be towards the transactional end of this spectrum (Dawson and Shaw, 1987). Relationships at this end of the spectrum are assumed to be inherently arms length and adversarial (Heide and Stump 1995, Ellram 1991, Carlisle \& Parker 1989). In this type of transactional relationship the primary goal of buyers is to minimise the price of purchased goods and services. Spekman (1998) argues that this is done by having a large number of suppliers who can be played off against each other to gain price concessions while still ensuring a continuity of supply. This model of buyer-seller relationships centres on homogeneity of supplies and substitutability of suppliers and as such does little to engender long term co-ordination or co-operation between buyer and supplier. Therefore, the traditional adversarial model is a classic case of win/lose, with both buyers and sellers spending considerable amounts of time searching for ways to capture some of the other party's margin.

The movement away from the traditional model was driven by the competitive pressures of the mid 1970s, such as the oil crisis and the onset of global competition (Lamming, 1993). These pressures exposed the weaknesses of the traditional model which was not able to respond quickly or efficiently to the need to reduce costs or improve quality due to the nature of the dealings between buyers and suppliers. Under this model costs could only be reduced by squeezing suppliers' prices which left them unable to invest in the systems needed to ensure the quality control required by manufacturers. Thus, for example, in the motor industry, where supply chain partnerships originated, Western companies, such as General Motors, engaging in traditional adversarial relationships found themselves losing market share to Japanese manufacturers such as Honda and Toyota who could produce cars of higher quality and at lower cost (Webster 1992, Lamming 1993).

Buyer-seller relationships in Japan involve partnerships with fewer, larger and more talented suppliers who are the sole sources of supply for varying components (Turnbull, Delbridge, Oliver and Wilkinson, 1993). These partnerships are based on co-operation, a full exchange of information, and a commitment to improve quality and reduce price. However one of the key distinguishing features of these relationships is that cost reductions and quality improvements are made by working together. Although suppliers still have to be highly competitive, under partnership arrangements cost reductions are achieved through cooperation rather than confrontation. They state that bargaining is not based on price per se but on how to reach the target price while maintaining a reasonable level of profit for the supplier. Therefore the focus of these relationships is on mutual benefit and as a result trust and collaboration replace mistrust and antagonism.

This pattern of co-operation was virtually unknown in the adversarial sourcing systems of US manufacturers and other researchers suggest that it was these co-operative partnerships that were giving Japanese competitors in numerous industries a competitive advantage against their western competitors. There is therefore a recognition that adversarial arms length purchasing relationships have historically robbed firms of the opportunity to gain a competitive edge. 
Supply chain partnerships have thus emerged as a panacea for improving a firm's competitiveness, and as such the literature suggests that there have been widespread moves to emulate Japanese manufacturing practices, particularly in the automotive industry (Landeros and Monczka 1989; Hamel et al 1989; Lyons et al 1990 Turnbull, Oliver and Wilkinson 1992; Heide \& Stump 1995; Mudambi \& Schrunder 1996).. However, while most partnership activity may have started in the car industry the movement towards closer relationships is seen to be a general trend that has been reported by numerous researchers in response to each industry's own set of competitive pressures. It is clear that supply chain partnerships are emerging at a pace in the food industry, driven by private incentives to secure market growth, gain market share, improve margins and increase efficiency, and public pressure for transparency, traceability and 'due diligence' throughout the food supply chain.

In discussing the movement towards relationships of a more cooperative nature, Spekman (1988) states that co-operative relationships seek to establish open lines of communication, nurture and sustain longer relationships between trading partners and develop mechanisms to solve differences such that the trading relationship is maintained to the mutual benefit of buyer and seller. He adds that philosophically such a model can only be built if trust and cooperation exist. Galt and Dale (1991) also suggest that emerging long-term supplier relationships require substantial changes in terms of behaviour and attitude. They state that these new types of relationships must be based on common aims, trust, cooperation, mutual dependency and a joint problem solving approach to problems. This is in line with Lyons, Krachenberg and Henke (1989) who argue that the new order of buyer-supplier relationships are characterised by cross functional teams and team decision making, longer term contracts and increased interdependence. The main motivation for developing supply chain partnerships is to gain competitive advantage. Successful companies today are those who have developed and are implementing a supply chain philosophy and that organisations who continue to operate adversarial relationships with suppliers and customers are eroding their competitive advantage. The adoption of a supply chain philosophy will increasingly become a critical success factor as market demands of globalisation, customer expectations and satisfaction and technology drive the requirement to co-operate.

The main motivation for partnering is to gain competitive advantage (Mohr \& Spekman 1994). For example, Ellram (1994) states that successful companies today are those who have developed and are implementing a supply chain philosophy and that organisations who continue to operate adversarial relationships with suppliers and customers are eroding their competitive advantage. Ellram also argues that the adoption of a supply chain philosophy will increasingly become a critical success factor as market demands of globalisation, customer expectations and satisfaction and technology drive the requirement to co-operate.

Numerous other researchers also suggest that the creation of closer relationships can help to improve a firm's competitive position and create benefits that are not possible using traditional arms length (Campbell 1988; Spekman 1988; Lyons, Krachenberg \& Henke (1989) Munday 1992; Ellram 1991). Indeed, the number of companies entering into or exploring customer/supplier alliances pays testimony to the extent of the perceived benefits involved. Yet, the quantitifcation of the benefits remains elusive to academic researchers.

The potential advantages of partnering from a customer perspective are: (1) easier management of a reduced supply base; (2) less time searching for new suppliers and tendering; (3) increased mutual dependence creates greater stability and loyalty and may 
increase supplier attention and service in areas such as lead time reliability, greater attention to common problems and priority in times of scarcity; (4) allows for joint planning and information sharing based on mutual trust and benefit; (5) better quality following from involvement of supplier in design, (6) reduced inventory levels, and (7) more stable supply prices (Ellram, 1991\& 1994).

The general impression of new buyer-supplier relationships is that manufacturing firms accrue significant advantages while their suppliers face significant disadvantages. Referring to interviews with purchasing managers from firms in a variety of industrial manufacturing industries Lyons, Krachenberg \& Henke (1989) suggest that both parties gain and lose something from the new arrangements. They suggest that buyers can benefit from: (1) reduced costs and improved quality; (2) reduced complexity and cost of buying; and (3) enhanced support relationships. On the other hand the disadvantages to buyers were identified as: (1) increased dependence; (2) the challenge of a new negotiating style; (3) less supplier competition; (4) new sources of added costs, (5) implementation of new reward structure; and (6) new and potentially risky channel interactions.

As the degree of partnership increases the buying firm typically enjoys significantly increased short-term productivity improvements and long term strategic advantages. The short term benefits, such as reduced downtime and rework, speedier throughput time and inventory reductions, are strongly related to the extent of the supplier partnership. The longer term benefits, such as reduced cost structure, product sales gains and improved product quality, show an even stronger relationship with the degree of partnership formed.

Suppliers also benefit from adopting a strategy of maintaining long term relationships with their customers compared to employing a transactional approach to servicing customers. Supplier firms in long term relationships are able to achieve a higher level of sales growth compared to suppliers that use a transactional approach to servicing customers. Furthermore they achieve higher profitability by differentially reducing their discretionary expenses and they are able to reduce inventory holding and control costs through more efficient inventory utilisation over time. However, firms in long term relationships often face lower gross margins over time, suggesting that supplier firms are forced to reduce prices to a greater extent than the reduction in costs through more efficient inventory utilisation.

While the majority of researchers have attempted to identify the benefits of supply chain partnerships and the reasons why they are expected to develop further, a number of researchers warn against the doctrine that partnerships are universally desirable. For example, although collaborative partnerships have been widely suggested as a source of competitive advantage they may not be appropriate for every trading relationship (Salmond \& Spekman, 1992). When parties recognise that the current state of their business requires no more than a minimal commitment they should agree not to collaborate, since non collaborators can enjoy a very long and profitable trading relationship. Similarly, it is unwise to assume that all trading relationships should warrant equal attention. In some instances establishing close ties may be more costly than beneficial and in other instances a potentially important relationship may be managed poorly and a strategic opportunity lost to competitors. Thus, not all trading relationships should be collaborative and, as Spekman, Kamauff and Myhr (1998) stress, it is acceptable to engage in arms length transactions provided that such behaviour is appropriate.

Researchers generally suggest that the degree to which a partnership can be developed will depend on the nature of the product market (Spekman 1988, Hughes 1996 Jackson 1985, 
Spekman \& Johnson 1991, Salmond \& Spekman 1992) and the nature of the powerdependence relationship (AT Kearney 1994; Frazier 1983; Gundlach \& Cadotte 1994; Kumar et al 1995, Frazier and Antia 1995; Spekman, Kamauff \& Myhr 1998). For example, while a more co-operative approach is evident, a number of purchasing decisions involve buying commodity-like goods and for these goods a more adversarial approach might be more appropriate. Collaborative relationships are not likely to be suitable for commodity purchases (even in high volume) and low value added goods. Partners involved in the purchase of these type of products may be linked through an inventory management system but the linkages may not pervade any other aspects of their business. Similarly, the extent of collaboration will be related to which industry they operate in and as such the type of product that is produced. For commodity products, long term contracts, and 'Just- in- time' inventory programs may generally represent the extent of potential collaboration.

\subsection{Efficient Consumer Response and the role of the 'Category Captain'}

Effective supply chain management requires trading partners to share long-term strategic objectives, develop mutual trust and work together to identify the most efficient and effective way of reaching their objectives. The emergence of Efficient Consumer Responses (ECR) in the US grocery industry in the early 1990s and its subsequent adoption in Western Europe, gave the process of developing effective supply chain partnerships was given a major boost

The fundamental principle of ECR is that through partnership within the global food supply chain, significant cost reduction (efficiencies) and improved performance (effectiveness) can be achieved through a better allocation of shelf space in the retail store, fewer wasteful promotions and new product introductions and more efficient physical replenishment. The key to the achievement of these goals is shared information, in particular, information on sales gathered at the checkout and transferred directly to suppliers through Electronic Data Interchange (EDI). Using this shared information, manufacturers and retailers can create more consumer value through the supply chain. Specifically, it is suggested that benefits can be accrued in four key areas: New Product Development; Promotions; Category Management; and Product Replenishment (see Table 11).

Whilst ECR brings many potential benefits to both suppliers and retailers, in terms of improvements in efficiency and effectiveness, the biggest opportunity it presents is to enable real supply chain collaboration. By sharing information it enables supply chains to effectively become demand chains, and in so doing to deliver enhannced customer value. For decades, food retailers (buyers) and manufacturers (sellers) have acted more as adversaries than as partners. Even though commercial realities will prevail so that individual entities in the supply chain will still seek competitive advantage, there now exists a framework in which they can co-operate not only to 'grow the cake' but to decide how it will be divided.

Table 11 The four pillars of ECR

\begin{tabular}{|l|l|l|l|}
\hline $\begin{array}{l}\text { Efficient New } \\
\text { Product } \\
\text { Introductions }\end{array}$ & $\begin{array}{l}\text { Efficient } \\
\text { Promotions }\end{array}$ & $\begin{array}{l}\text { Efficient Range and } \\
\text { Assortment }\end{array}$ & $\begin{array}{l}\text { Efficient Product } \\
\text { Replenishment }\end{array}$ \\
\hline $\begin{array}{l}\text { Improve success } \\
\text { rate }\end{array}$ & $\begin{array}{l}\text { Improve } \\
\text { consumer } \\
\text { targeting }\end{array}$ & $\begin{array}{l}\text { Match to } \\
\text { consumer and } \\
\text { shopper needs }\end{array}$ & $\begin{array}{l}\text { Improve on-shelf } \\
\text { availability } \\
\text { Reduce costs }\end{array}$ \\
\hline
\end{tabular}




\begin{tabular}{|c|c|c|c|}
\hline $\begin{array}{l}\text { market } \\
\text { - Improve return } \\
\text { on investment } \\
\text { - Improve quality } \\
\text { and reduce costs }\end{array}$ & $\begin{array}{l}\text { Improve return } \\
\text { on investment } \\
\text { Co-operation } \\
\text { across the supply } \\
\text { chain }\end{array}$ & 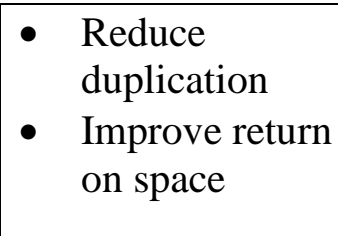 & - $\quad$ Reduce inventory \\
\hline
\end{tabular}

Source: Adapted from Christopher, M. 1998. Logistics and Supply Chain Management. Pitman Publishing, U.K.[

Within the ECR paradigm, the concept and practice of category management (CM) has created the position of 'Category Captain'. Retailers may select a 'Category Captain' to work with retail staff to create a plan for the entire category, including competitors' brands and private label brands. The CM planning process, often, leads to a reduction in the number of SKU's being carried by the retailer. As a result, it takes significant objectivity for the category captain to resist the temptation to make a case for delisting its competitors and maximising shelf space for its company's own brands.

The retailers' expectations of 'Category Captains' in FMCG product categories are at a higher level than those who are in the fresh food categories - characterised by smaller-scale companies operating on lower margins, with less resources to invest in category research. Overall, however, the more forward-thinking retailers seek, at a minimum, the following from their preferred suppliers and 'Category captains':

- pro-active relationships across all areas and levels of the business - pre-CM and before the major FMCG companies adopted more progressive customer management practices, the relationship between retailer and manufacturer, largely, rested on the manufacturer account manager liaising with the retail buyer. All others were excluded, lest they obfuscate the commercial process. With the arrival of $\mathrm{CM}$ and the formation of retail cross-functional category teams and their counterpart teams at the manufacturer level, communication is, generally, encouraged at all levels across the two businesses, for example: shipper with receiver; NPD with NPD; Quality Assurance with the retail technical staff; as well as the respective category team managers;

- increasingly, complete electronic integration is becoming a requirement and, fortunately, as the cost of IT equipment declines, EDI is becoming financially feasible for smallerscale companies. Vendor-managed inventory is becoming the norm for progressive retailers and electronic integration is a sine qua non for this activity;

- sharing a comprehensive range of information directed at improving existing and building future business. As retailers come to terms with the fact that unused piles of scan data is a problem, but, information from carefully analysed sales data is a solution, then, the historic reluctance of the retailer to share data is slowly overcome; particularly, when the supplier provides the analytical capability. However, suppliers must learn to provide information to retailers and to resist the temptation, for example, to withhold notice of a problem until it is too late for the retailer and manufacturer to develop an appropriate solution;

- as identified in the previous section, retailers seek suppliers who show excellence in innovation - in NPD, but also, in supply chain management, finance etc.; 
- suppliers who understand the role and structure of the category and who can assist the retailer in forecasting its future development. This skill is particularly important in mature food product categories (the majority) in which the supermarket chains have $80+$ per cent market share and sales/profitability growth can only come from the application of sound business strategy;

- suppliers who show sufficient commitment to each key customer that they are willing to develop customer-specific products and services;

- and suppliers who have the objectivity and knowledge to develop jointly a strategy for mutual business growth.

Forging successful partnerships between historic adversaries - retailers and manufacturers - is a challenge that stands or falls on both parties committing to the idea, communicating the purpose within their respective organisations and between themselves, and showing continuity of effort (the longer the partnership survives, the more likely it is to last, as the two parties and, particularly the supplier gains the self-confidence to point out problems). In Table 11, the major factors that influence successful establishment and sustained operations of partnerships and alliances are identified. Each of the twenty factors are of significance, but, three that should be reiterated are: clear benefits (although, not necessarily equal benefits) for each partner; partners should share the same long-term objectives; and aim for leadership in quality as it makes it difficult for others to follow. 


\section{Table 11 Major Factors that Influence Successful Establishment and Sustained Operations of Supply Chain Partnerships}

1. Clear benefits for all partnership and alliance members.

2. Business proposition underpinning the partnership that makes long-term commercial sense.

3. Focus on specific partnerships, products and markets.

4. Build upon successful partnerships.

5. Apply lessons learnt from the partnership to gain benefits in other business areas.

6. Partners/alliance members should have a good strategic fit.

7. The commercial relationship should be based on interdependence.

8. Companies have similar corporate values and the same commercial ethos.

9. Mutual trust and respect.

10. Aim high on quality - make it difficult for others to follow.

11. For junior partners: pick a senior partner with a long-term commercial future

12. Build relationships and communication links between all levels of the two businesses.

13. Gain full endorsement of the venture by the most senior management and strong personal commitment of all staff.

14. Members should hold a common view on the long-term objectives of the partnership.

15. Partnership members should hold a common view of what the final consumer wants.

16. Raise the veil of secrecy and focus on sharing information required to make the partnership a success.

17. Investment in physical plant and, for horizontal partnerships, joint investment by members builds commitment to the venture.

18. Build flexible organisations that meet the specific needs of each partnership.

19. Fix problems as they arise - delays only serve to disrupt.

20. To ensure success, partnerships require their fair share of commercial good fortune.

Source: Hughes, D. and D. Ray. 1994. Factors Determining Success in Partnerships \& Alliances. Pp.199-215. Chapter 10. In Hughes, D. (ed.). Breaking with Tradition: Building Partnerships \& Alliances in the European Food Industry. Wye College Press, University of London, Wye, Kent, U.K.

\subsection{Conclusions}

In the 1950s, manufacturers were the 'Category Captains' - the pivotal point between many raw material suppliers and the myriad of small shops that comprise the independent grocery trade. In Europe and North America, the major retailers have taken over the captaincy. In increasingly concentrated, mature, slow-growth markets, major supermarket companies seek means to differentiate themselves from the competition. One such way is to build unique supply chains - with exclusive commitment from chain members, manufacturers and farmers, and an exclusive range of products. The premium private label product programs of U.K. retailers are addressing exactly this issue; building a product offer that is not directly comparable and, hopefully, discernibly better than immediate competitors. Each retailer wishes to corral the "best" suppliers and, in turn, the "best" raw material producers in their respective supply chains and deny access to these "best" members to the competition.

What is emerging is the antithesis of neo-classical perfect competition, indeed, it is supply chain-based competition. The food industry is not unique in this regard; indeed, co-operation rather than confrontation in the supply chains has underpinned the substantial productivity improvements that have been characteristic of the motor car industry, for example. Members of specific supply chains share a common commercial interest, i.e. increasing the market share and profitability of their supply chain. In supply chains where the relationships 
between the channel captain and other members is adversarial, then, this mutuality of interest collapses. Unfortunately, in many countries, the retailers - as 'Category Captains - are oriented predominately towards controlling the supply chain, and to doing so through threatening behaviour and engendering fear; the threat of delisting and the fear of being delisted.

Successful supply chains will be those that embrace the notion of the "learning chain". In his seminal work on building learning organisations, Peter Senge identified that "over the long run, superior performance depends on superior learning". Further, "Leaders engaged in building learning organisations ....... (should seek) to change the way businesses operate From a conviction that their efforts will produce more productive organisations, capable of achieving higher levels of organisational success and personal satisfaction than more traditional organisations". Senge identifies three critical areas of skills for establishing a learning organisation, viz. building shared vision, challenging conventional wisdom and current practice without inducing defensiveness, and engaging in systems thinking. These three skills are directly relevant to building a "learning chain". Unfortunately, they are not skills that are abundantly evident or, indeed, available in the skill set of many senior retail category managers as we enter a new century.

\section{SUMMARY}

Competition in the food industry of the $21^{\text {st }}$ Century is being played on a global field, with fewer, larger, global players battling for market share. The stalemate which results from global retailers confronting global manufacturers has been broken by the introduction of Efficient Consumer Response (ECR) and the realisation that co-operation between trading partners is more effective than confrontation. Traditional inter-firm competition is being superseded by competition between supply chains, as retailers and manufacturers alike seek competitive advantage through strategic supply chain partnerships. The food industry has been slow to emulate the success of the motor industry and it is only in recent years that supply chain management has made its way onto the boardroom agendas of the world's leading food manufacturers. However, the introduction of ECR in the 1990s, represented a paradigm shift in the operation of the food supply chain, with adversarial trading relationships being replaced by co-operation and co-ordination, facilitated by a willingness to exchange information of both strategic and operational importance. As a result, the world's leading food manufacturers are shaving days off of production lead times, weeks off of inventory levels and months off of New Product Development (NPD) cycles, delivering a more effectively managed range of carefully targeted products and services to increasingly diverse groups of consumers, at substantially lower costs. The commodity sectors have still a long way to catch up, but it is evident that throughout the global food industry supply chain management is here to stay and likely to remain a key point of focus for the leading players in the future.

\section{REFERENCES}

Brandenburger, A.M. and Nalebuff, B.J.(1996), Co-opetiton, Doubleday, New York.

Bhote, K.R. (1989), Strategic Supply Management, Amacom, New York.

Carlisle, J. and Parker, R. (1989), Beyond Negotiation, Wiley, Chichester. 
Christopher, M. 1992. Logistics and Supply Chain Management. Pitman Publishing, U.K

Christopher, M (1997), Marketing Logistics, Butterworth Heinemann, Oxford.

Connor, J.M. and W.A. Shiek. 1997. Food Processing: An Industrial Powerhouse in Transition. Second Edition. John Wiley \& Sons, New York, U.S.A

Cooper M And Ellram L, 1993. Characteristics Of Supply Chain Management And The Implications For Purchasing And Logistics Strategy, The International Journal of Logistics Management, Vol.4, No.2.

Cox, A. and Lamming, R. 1997. Managing Supply in the Firm of the Future, European Journal of Purchasing and Supply Management, No.2

Cox, A. 1999. Power, value and supply chain management, International Journal of Supply Chain Management, Vol.4, No.4

Ellram, L. 1995. Partnering Pitfalls and Success Factors, International Journal of Purchasing and Materials Management, Spring 1995.

Fearne, A. \& Mawson, E. 1997. "Partnerships and alliances in the food service sector opportunities with fast food restaurant chains", Farm Management Journal, Vol.9, No.11

Fearne, A. 1998. The evolution of partnerships in the meat supply chain: insights from the British beef industry, International Journal of Supply Chain Management, vol.3, No.4.

Fearne, A. \& Hughes, D. 1999. Success factors in the fresh produce supply chain: insights from the UK, International Journal of Supply Chain Management, Vo.4, No.3.

Gattorna, J.L. and Walters, D.W. (1996), Managing the Supply Chain, Macmillan, Basingstoke.

Hamel, G. and Prahalad, C.K. (1990) "The Core Competence of the Corporation", Harvard Business Review, (May-June).

Harland C, 1996. Supply Chain Management: Relationships, Chains And Networks,_British Journal Of Management, Vol 7.

Harlow P, 1994. Category management: A new era in EMCG buyer-supplier relationships, Journal of Brand Management, Vol.2, No.5.

Harrison, A (1993), Just-in-Time Manufacturing in Perspective, Prentice Hall, London.

Hines, P. (1994), Creating World Class Suppliers, Pitman, London.

Hobbs,J. 1996. A transaction cost approach to supply chain management, International Journal of Supply Chain Management, Vol.1, No.2.

Houlihan, J (1988), "Exploiting the Industrial Supply Chain", in Mortimer, J (ed)., Logistics in Manufacturing, IFS Publications, London. 
Hughes, D. and D. Ray. 1994. Factors Determining Success in Partnerships \& Alliances. Chapter 10. In Hughes, D. (ed.). Breaking with Tradition: Building Partnerships \& Alliances in the European Food Industry. Wye College Press, University of London, Wye, Kent, U.K.

Hughes, D. and D. Ray. 1999. The Global Food Industry in the $21^{\text {st }}$ Century, Food Industry Management, Wye College, University of London.[

Kay, J, (1993), Foundations of Corporate Success, OUP, Oxford.

Kumar, N.1996. The Power of Trust in Manufacturer/Retailer Relationships, Harvard Business Review, Nov.Dec, 1996.

Lamming, R. (1993), Beyond Partnership, Prentice Hall, New York.

Lewis, J.D. (1990), Partnerships For Profit, Free Press, New York.

Lorange, P. \& Roos, J. 1993. Strategic Alliances: formation, implementation and evolution, Blackwell Business.

Marion, B.W. 1998. Changing Power Relationships in US Food Industry: Brokerage Arrangements for Private Label Products. Pp. 85-93. Agribusiness. Volume 14, No. 2. 1998

Mighell, R.L. and Jones, L.A. (1963). Vertical Coordination in Agriculture, USDA ERS-19, Washington DC.

Moore, J.F. (1996), The Death of Competition, Harper Collins, New York.

Moss-Kanter, R. 1994. Collaborative Advantage: The Art of Alliances, Harvard Business Review, July-Aug 1994.

O’Keeffe, M. 1996. Establishing supply chain partnerships: lessons from Australian agribusiness, International Journal of Supply Chain Management, Vol.3, No.1.

Passingham, J.1998. Grocery Retailing and the Loyalty Card. Pp. 55-63. Journal of the Market Research Society. Volume 40, No. 1. 1998.

Porter, M. 1980. Competitive Strategy. Chapter 2, pp. 34-46. The Free Press. Macmillan Publishing, U.S.A.

Porter, M. 1985. Competitive Advantage. The Free Press. Macmillan Publishing, U.S.A.

Sako, M (1992), Prices, Quality and Trust, CUP, Cambridge.

Saunders, M. (1994), Strategic Purchasing and Supply Chain Management, Pitman, London.

Senge, P.M. 1990. The Leader's New Work: Building Learning Organizations. Sloan Management Review, 7, Autumn 1990.

Sporleder, T.L. (1992). Managerial Economics of Vertically Coordinated Agricultural Firms, 
American Journal of Agricultural Economics, 74, 5, December.

Wileman, A. and M. Jary. 1997. Retail Power Plays; From Trading to Brand Leadership. Macmillan Business Press, London, U.K.

Womack, J.P, Jones, D.T. and Roos, D. (1990), The Machine That Changed the World, Rawson Associates, New York. 